\title{
Feeding preferences of the herbivorous crab Grapsus albolineatus: the differential influence of algal nutrient content and morphology
}

\author{
Robin Kennish*, Gray A. Williams \\ Department of Ecology \& Biodiversity and The Swire Institute of Marine Science, The University of Hong Kong, \\ Pokfulam Road, Hong Kong
}

\begin{abstract}
The tropical rocky shore crab Grapsus albolineatus selectively consumes rare filamentous algae over more abundant foliose algae during the winter in Hong Kong. Laboratory experiments have shown that growth of $G$. albolineatus is enhanced and mortality reduced when given a diet of filamentous algae as opposed to foliose algae. In the laboratory, $G$. albolineatus consumed filamentous algae (Enteromorpha clathrata, Hincksia mitchelliae and Chaetomorpha antennina) in greater amounts than any foliose algae (Dermonema frappieri, Pterocladia tenuis, Porphyra suborbiculata, Ulva fasciata, Endarachne binghamiae) in both multiple choice and no choice experiments. The most energy-rich alga was Pterocladia, while Porphyra had the highest protein content. Filamentous algae had lower overall nutrient contents than foliose algae. Consumption rates for Enteromorpha and Hincksia were, however, sufficiently higher than for Porphyra, which ensured that the net intake of nutrients per day was greater. Even though protein assimilation efficiency was higher for Porphyra than Hincksia, $G$. albolineatus assimilated more protein, per day, from Hincksia. When the confounding effects of morphology and nutrient value were separated, by offering the crab choices of commercially available algae (Laminaria sp.) cut into different forms (foliose and filamentous), G. albolineatus showed a strong preference for the filamentous form, despite both forms having the same nutrient value. Preference for filamentous forms is likely to be constrained by the morphology of the chelae, which have delicate tips, and appear unable to tear foliose algae. Algal morphology, therefore, appears to be of prime importance and the nutrient content and digestibility of algae of secondary importance in determining the feeding preferences of $G$. albolineatus. The high consumption rate of filamentous algae outweighs their relative nutrient deficiencies, indicating that they are better suited to meeting the physiological needs of the crab than foliose algae.
\end{abstract}

KEY WORDS: Diet - Consumption rate A Algal morphology - Crab - Tropical rocky shore - Herbivore Nutrients - Protein

\section{INTRODUCTION}

The prime directive of all organisms is to obtain food for survival, growth and reproduction (White 1993). Obtaining food is a complex process involving search for, discrimination between and acquisition of potential food types. Discriminatory processes have evolved in many organisms to show a preference for particular food types, often types that satisfy the physiological needs and contribute most to the growth and eventual

\footnotetext{
•E-mail: rk@ermhk.com
}

reproduction of the organism (Nicotri 1980, Watanabe 1984). Numerous examples of feeding preference studies have been documented for marine herbivores, including molluscs (Carefoot 1980, Jensen 1983, Watson \& Norton 1985, Steinberg 1985, Norton et al. 1990), urchins (Lowe \& Lawrence 1976, Prince \& Leblanc 1992), amphipods (Robertson \& Lucas 1983, Arrontes 1990, Duffy 1991), fish (for reviews see Horn 1989, Choat 1991) and iguanas (Wikelski \& Trillmich 1994).

In comparison with other animal groups (e.g. molluscs), studies on the preferences of decapods are rare, especially for herbivorous decapods (reviewed by Wolcott \& O'Connor 1992). Preferences of herbivorous 
crabs have been examined in a range of habitats, e.g in the terrestrial environment (Cardisoma carnifex; Lee 1988) and in mangroves (Aratus pisonii on living leaves; Beever et al. 1979). On rocky shores, preferences of grapsid crabs have been examined; Hemigrapsus nudus has been documented to prefer green over red and brown algae (Birch 1979) and Pachygrapsus crassipes to prefer Ulva and Enteromorpha (Hiatt 1948), although these observations were based on gut content data. Grapsus grapsus in the Galápagos Islands has been observed to prefer Ulva as compared to red and brown turf species (White 1993).

Several criteria are assumed to influence food choice in herbivores (reviewed by Lubchenco \& Gaines 1981). These criteria include algal nutritional characteristics (Watson \& Norton 1985), morphology (Jensen 1983), availability (Arrontes 1990) and chemical composition (Hay \& Steinberg 1992), and the nutritional requirements of the herbivore (Watanabe 1984), its digestive capabilities and its mode of feeding (Lowe \& Lawrence 1976). In Hong Kong, the rocky shore crab Grapsus albolineatus Lamarck selectively consumes filamentous algae, specifically green and brown turf species (Kennish et al. 1996), despite the fact that these algae are not the most abundant species on the shore at any time of the year (Kennish 1997a). The aim of the present study is to determine whether the feeding preferences of $G$. albolineatus are nutritionally based or whether the alga's morphology ultimately determines its status as a preferred food species. To evaluate this, a series of choice experiments were performed to examine whether $G$. albolineatus preferred nutrientrich algae. Such tests, using species of different nutritional value, are confounded by morphological differences amongst the algae. To isolate algal morphology as a determining factor for preference crabs were offered the same alga (re-hydrated commercially available kelp) in both filamentous and foliose form.

\section{MATERIALS AND METHODS}

Algae and crabs were collected from rocky shores at Cape d'Aguilar, Hong Kong $\left(22^{\circ} \mathrm{N} ; 114^{\circ} \mathrm{E}\right)$. Experiments were conducted during late February 1995 (no choice \& multiple choice) and early July 1996 (form choice). Crabs used were adults, of similar size (42 to $52 \mathrm{~mm}$ carapace width), and in all experiments a 1:1 sex ratio was used

The algal species used were chosen according to their relative abundance on the shores of Cape d'Aguilar, their morphological structure and their relative contribution to the observed diet of Grapsus albolineatus (see Kennish et al. 1996). The 8 algal species are present at overlapping times of the year within the foraging range of the crab and all were present on the shores during the experimental period. They are referred to in this paper by genus name; their full names are given in Table 1 . An initial aim was to use the same species in the no choice tests and in the multiple choice tests; however, due to extreme weather conditions at the study site preventing collections, Pterocladia had to be used in the multiple choice tests instead of Dermonema, although no replacement could be found for Chaetomorpha. The algae were divided into 2 groups based on their morphology: Filamentous group, Enteromorpha, Chaetomorpha and Hincksia; all 3 are present in the diet of the crab despite being rare on the shore. Foliose group, Porphyra and Ulva, which are abundant on the shores but infrequent dietary items (Table 1), and 3 other foliose species, Dermonema, Endarachne and Pterocladia (overall shore abundance $0.33 \%$, but common on the extreme low shore $\sim 10 \%$ )

Feeding preference tests: general methodologies. Two types of tests were used to analyse the feeding preferences of Grapsus albolineatus. In the first series of tests the crabs were offered only one species of

Table 1. Algal species used to test the feeding preferences of Grapsus albolineatus. Values illustrate the total shore cover and the percentage contribution to the crab's diet for each species, taken from data for February 1994 (Kennish et al. 1996). Morphological descriptions are adapted from Littler et al. (1983)

\begin{tabular}{|c|c|c|c|}
\hline Alga & Morphological description & $\begin{array}{c}\text { Shore } \\
\text { cover }(\%)\end{array}$ & $\begin{array}{c}\text { Dietary } \\
\text { contribution }(\%)\end{array}$ \\
\hline \multicolumn{4}{|l|}{ Filamentous group } \\
\hline Enteromorpha clathrata (Roth) J. Agardh & Multiseriate, highly branched, tubular, filamentous & 3.35 & 40.56 \\
\hline Chaetomorpha antennina (Bory) Kuetz & Uniseriate, filamentous & 5.56 & 8.92 \\
\hline Hincksia mitchelliae (Harvey) Silva & Uniseriate, branched, filamentous & 6.55 & 22.59 \\
\hline \multicolumn{4}{|l|}{ Foliose group } \\
\hline Ulva fasciata Delile & Distromatic, sheet-like, foliose & 11.81 & 0.14 \\
\hline Porphyra suborbiculata Kjellman & Distromatic, sheet-like, foliose & 6.59 & 4.73 \\
\hline Dermonema frappieri (M. \& M.) Borg & Coarsely branched rubbery thallus, upright, foliose & 7.18 & 0 \\
\hline Pterocladia tenuis Okamura & Coarsely branched fleshy thallus, recumbent, foliose & 0.33 & 0 \\
\hline Endarachne binghamiae J. Agardh & Thick blade, differentiated, leathery thallus, foliose & 4.23 & 0 \\
\hline
\end{tabular}


alga, thereby allowing calculation of consumption rate over a known period. These tests are valuable in emphasising the plasticity of an animal's feeding preferences, as even though an alga may be avoided in nature, when only one food type is present the animal may respond differently. This test also gives an indication of handling time and reflects differences in the attractiveness/palatability of the various potential foods.

In the second test each crab was simultaneously offered 6 different algal species. This is a more rigorous method for analysing feeding preferences since, unlike the previous test, it involves direct selection through both tactile and chemosensory responses (Coen 1988).

For each experiment the crabs were individually placed into plastic aquaria (see Kennish 1996) and allowed to acclimate to laboratory conditions for $4 \mathrm{~d}$ (under a natural light $/$ dark cycle; salinity $=37 \%$; temp., Feb $=18^{\circ} \mathrm{C}$, Jul $=28^{\circ} \mathrm{C}$ ). For each test the crabs were given algal thalli previously rinsed in filtered seawater with all faunal epiphytes removed. These organisms were not expecially dense on the algae but were removed to ensure they did not alter the mass of the alga by consuming it and also because they may affect the choice of the crab. The algae were blotted and weighed to the nearest $0.001 \mathrm{~g}$. Exactly the same procedure was used for the control algae. The algal controls were run simultaneously in the same type of aquaria but without the crab. Effort was made to use approximately equal sizes and weights of algae but, due to differences in morphology, this was often not possible. The presentation of the algae to the crabs in the experiments was such that there was no change in 'form' when compared to algae on the shore. That is, whole algae were always used, loosely threaded through the mesh of the container so they were anchored in some way.

The filamentous algae ranged between 2 and $6 \mathrm{~g}$; the foliose algae were of similar size (volume) but heavier ( 7 to $14 \mathrm{~g}$ ). At the end of the tests the algae from control and crab treatments were blotted and reweighed. Careful collection was made of all fragments torn loose by the crabs. The same number of controls as tests with crabs were set up to account for any autogenic changes in the mass of the test algae. Differences between control and crab treatment algal weights were determined to calculate the amount eaten by the crab, by randomly assigning treatment/ control pairs (Peterson \& Renaud 1989). This procedure was repeated 5 times and no significant difference was observed between the different pairs so for all tests one initial random pairing was used (1-way ANOVA, df $=4, F<0.01, p>0.999$ ). Two measurements were calculated, mass change (g) and \% con- sumed. Both methods were used as the latter is sensitive to differences in size and weight of the test algae (Coen 1988).

Feeding preference tests: no choice. The duration of these tests was $36 \mathrm{~h}$, starting in the evening. Ten crabs were used for each of the 7 algae [listed in Table 4 , $\Sigma n=10$ crabs $\times 7$ algae $\times 2$ (test and control) $=140$ l . The design of the aquaria allowed faecal pellets to be collected at the end of the test. These were dried to constant weight at $45^{\circ} \mathrm{C}$ and weighed to the nearest $0.001 \mathrm{~g}$. Differences between the algae in mass change and \% consumed were analysed using 1-way ANOVA, or the Kruskal-Wallis test if the assumptions of ANOVA were violated. Multiple comparison procedures (SNK or non-parametric equivalent, Zar 1996) were performed to investigate significant differences. All statistical procedures were carried out using SigmaStat software (Jandel Scientific).

Feeding preference tests: multiple choice. Crabs were simultaneously given pre-weighed pieces of the 6 test algae (see Table 4 ). Ten crabs were used, and the experiment was repeated 3 times $\left[\sum n=10\right.$ crabs $\times 3 \times$ 2 (test and control) $=60$ ]. The test was run for longer than the single choice experiment ( $t=48 \mathrm{~h}$ ) so as to allow the crabs time to encounter all the algal species. ANOVA cannot be used to analyse the results of this experiment as the data violate the assumption of independence (Peterson \& Renaud 1989, Roa 1992, Manly 1993) so differences among species were not examined. A Mann-Whitney test was, therefore, used to investigate differences in mass change between control and test algae.

Differences in the consumption rate $\left(g 24 \mathrm{~h}^{-1}\right)$ between the no choice and the multiple choice tests for the 5 species of algae used in both tests were tested using a Mann-Whitney test.

Feeding preference tests: form choice. In this experiment the crabs $\left[\sum n=18\right.$ crabs $\times 2$ (test and control) $=36$ ] were presented with 2 manipulated forms of the same alga (commercially bought kelp Laminaria sp. as a standard). Use of a commercially available and novel alga ensured that crab choice would not be influenced by previous experience and also reduced variability between treatments. The alga was rehydrated in seawater for $30 \mathrm{~min}$ and then cut using a scalpel into 2 different shapes; the foliose form measured $>30 \mathrm{~mm}$ width, and the filamentous form measured $<3 \mathrm{~mm}$ width, with both forms between 60 and $100 \mathrm{~mm}$ length $(\sim 2$ to $4 \mathrm{~g})$. Organic content (AFDW) of both forms was measured to ensure that cutting the thallus had no influence on food quality. As for the multiple choice tests, experimental duration was $48 \mathrm{~h}$ so that the crabs could encounter both form types: differences in consumption were analysed using a Mann-Whitney test. 


\section{RESULTS}

\section{Feeding preference tests: no choice}

Crabs exhibited clear differences in relative consumption of the test algae. The highest consumption was recorded for the filamentous species Enteromorpha, Hincksia and Chaetomorpha; crabs consumed slightly less Porphyra and showed little or no consumption of the remaining 3 foliose species (Fig. 1). The preference order of the species varied slightly according to whether mass $(\mathrm{g})$ consumed or percentage of alga consumed (Fig. 1) was examined, although the general pattern was similar. The different rankings were due to initial variation in the weights of the test algae as a consequence of attempts to give the crabs similar sized algal thalli (see also Lewis 1985, Coen 1989). The filamentous algae were consumed in significantly greater amounts than all of the foliose algae, except for Porphyra, which was eaten in significantly greater amounts than Dermonema, Ulva and Endarachne (Table 2).
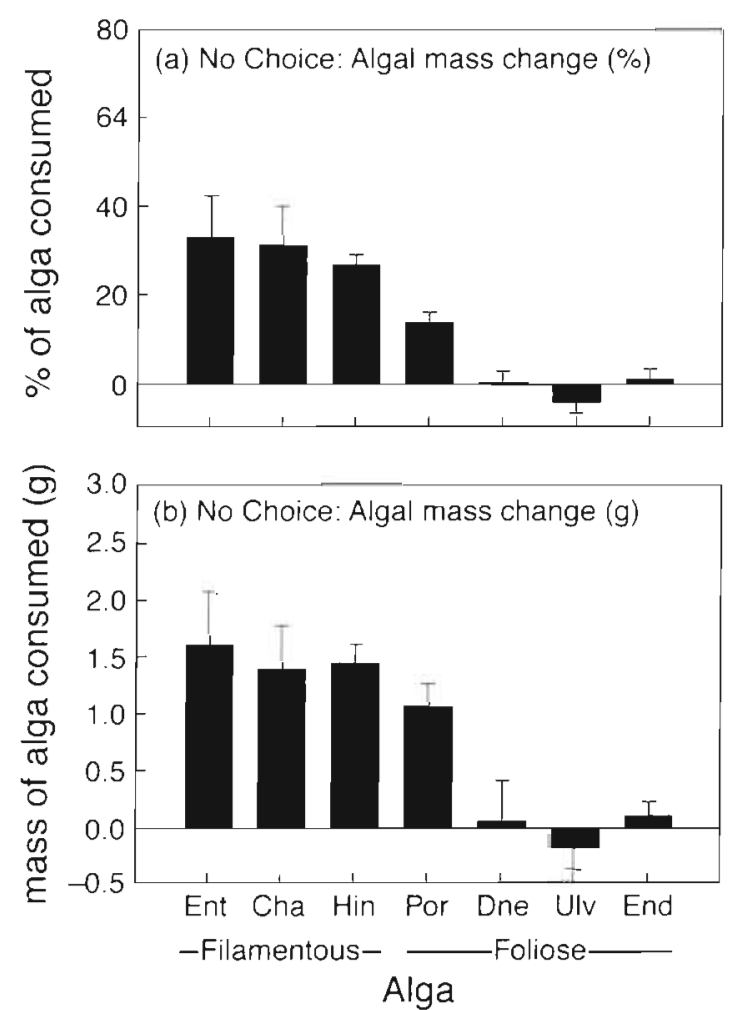

Fig. I Grapsus albolineatus. No choice feeding preference tests for 7 macroalgae (abbreviations listed in Table 4). (a) Mean \% of alga consumed ( $+\mathrm{SE}$ ). (b) Mean mass of alga consumed ( $+\mathrm{SE})$. In the case of Ulva, greater mass was lost in the controls, accounting for the apparent negative consumption
The small amounts of faeces produced by the crabs made individual collections impossible, so faeces from crabs fed the same alga were pooled. The largest mass of faecal pellets was collected from crabs feeding on Enteromorpha and Chaetomorpha (1.06 and $0.75 \mathrm{~g}$ respectively). Smaller amounts were collected from crabs feeding on Hincksia, although this was still greater than for all the foliose algal species (Fig. 2).

\section{Feeding preference tests: Inultiple choice}

As with the no choice experiment, the preferred/most heavily consumed species were the filamentous algae. Consumption of Enteromorpha and Hincksia was 10 times greater than for Porphyra and Ulva (Fig. 3). The filamentous algae accounted for $91 \%$ of the total amount of algae consumed (g) during the experiment. There were significant differences in algal weight loss between control algae and experimental algae for all species except Endarachne and Pterocladia, which were not consumed by the crabs (Fig 3). As in the single choice experiment, rankings differed slightly between results for percentage and mass consumption. Enteromorpha was consumed most in terms of mass,

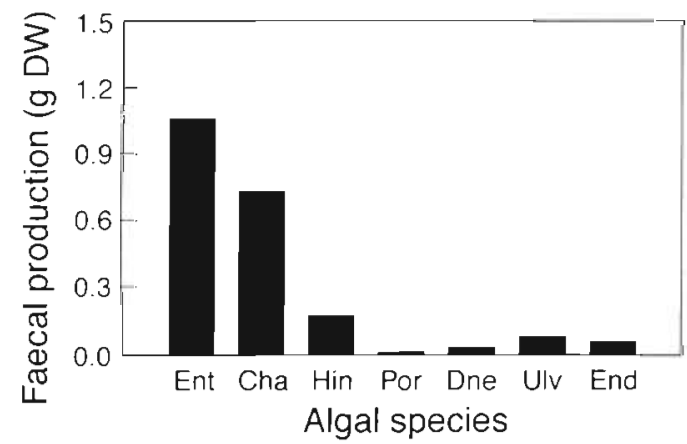

Fig. 2. Grapsus albolineatus. Total amounts of taeces produced when feeding on different algae during the $36 \mathrm{~h}$ long no choice preference experiment (abbreviations as in Table 4) 

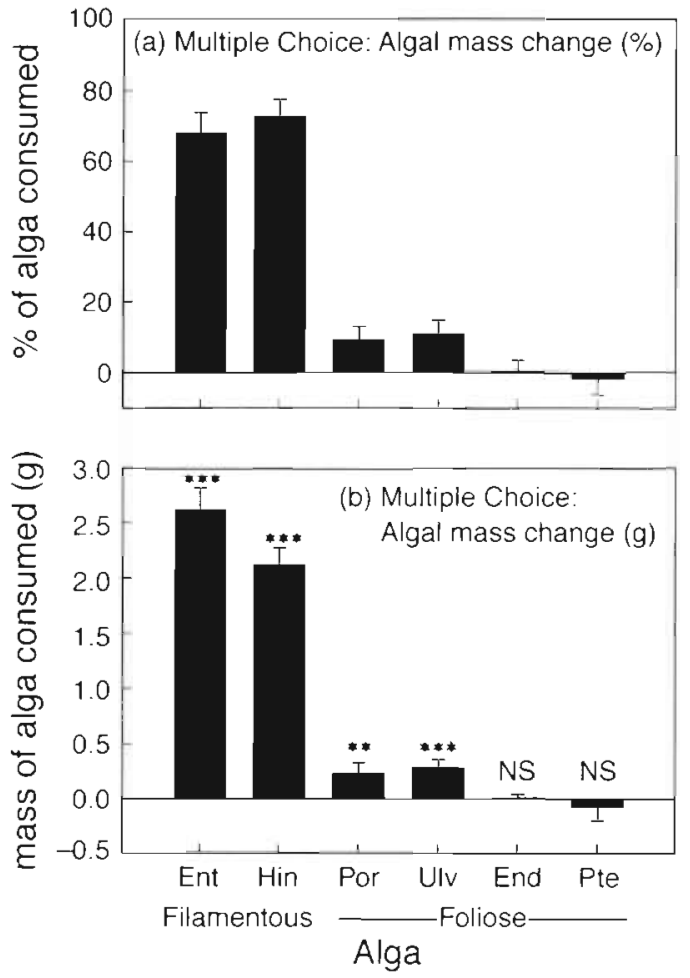

Fig. 3. Grapsus albolineatus. Consumption of 6 macroalgae simultaneously offered in a multiple choice preference test $(+\mathrm{SE})$. Asterisks indicate that mass loss in experimental algae was significantly different from mass loss by controls $" p<$ $0.05 ; \cdots p<0.001$; NS: not significant, Mann-Whitney test)

whereas a greater percentage of Hincksia was consumed.

When comparing consumption rates (g $24 \mathrm{~h}^{-1}$ ) for the 5 algae used in both the no choice and multiple choice tests it can be seen that the presence of other algae alters the preference (in terms of consumption) of Grapsus albolineatus. Porphyra was consumed significantly faster when it was offered on its own. Hincksia and Ulva, however, were consumed more rapidly in the presence of other algae. Consumption of Enteromorpha did not differ between the tests, although it was consumed faster than any other algae (Table 3).

Table 3. Grapsus albolineatus. Consumption rate differences between the 2 feeding preference tests. NC: no choice test; MC: multiple choice test (Mann-Whitney test)

\begin{tabular}{|lcc|}
\hline Alga & $\mathrm{p}$ & Median comparison \\
\hline Enteromorpha & $\mathrm{ns}$ & $\mathrm{NC}=\mathrm{MC}$ \\
Hincksia & $<0.001$ & $\mathrm{MC}>\mathrm{NC}$ \\
Porphyra & $<0.001$ & $\mathrm{NC}>\mathrm{MC}$ \\
Ulva & $<0.05$ & $\mathrm{MC}>\mathrm{NC}$ \\
Endarachne & $\mathrm{ns}$ & $\mathrm{NC}=\mathrm{MC}$ \\
\hline
\end{tabular}

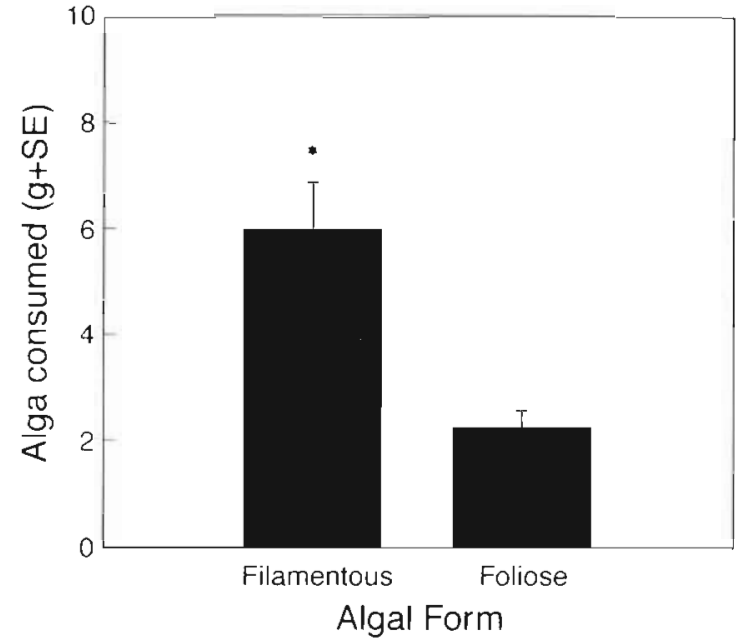

Fig. 4. Grapsus albolineatus. Consumption of simultaneously offered filamentous and foliose forms of test algae $(g+S E)$.

- Indicates that consumption was significantly greater for the filamentous form of algae ( $\mathrm{p}=0.002$, Mann-Whitney test)

\section{Feeding preference tests: form choice}

Grapsus albolineatus consumed significantly more of the filamentous form of the test alga than the foliose form (Fig 4; Mann-Whitney test, $U=242$, df $=1, \mathrm{p}=$ $0.002)$. There was no significant difference between the organic contents of the thallus of the 2 algal forms (Mann-Whitney Test), indicating that cutting the thallus did not cause a difference in nutrient value of the 2 forms.

\section{Macroalgal nutritional composition}

The nutritional quality of the test algae varied between the species (Table 4, data taken from Kaehler \& Kennish 1996). The most energy-rich alga was Pterocladia; Enteromorpha had the lowest calorific value. Ash content varied from 42.5 (Chaetomorpha) to $10.8 \%$ (Porphyra), soluble carbohydrates from 8.10 (Hincksia) to $33.7 \%$ (Dermonema), protein from 1.3 (Ulva) to $11.2 \%$ (Porphyra), total lipids from 0.3 (Porphyra) to $2.5 \%$ (Endarachne), carbon from 24.6 (Enteromorpha) to $39.1 \%$ (Porphyra) and nitrogen from 1.4 (Enteromorpha) to $4.6 \%$ (Pterocladia).

The algae can be divided clearly into groups based on taxonomic division and not form, since the 3 filamentous species have very different nutrient contents. The Chlorophyta, for example, had the highest ash content, the red algae were typically rich in soluble carbohydrate and nitrogen and the brown algae Hincksia and Endarachne had the highest lipid content. Seasonal variation in nutritional composition is considered to be of little importance in Hong Kong 
Table 4. Energy and nutritional composition of the algal species used in the feeding preference tests. 'Both' indicates that the alga was used in both the no choice (NC) and the multiple choice (MC) tests. Abbreviations are those used in all figures. Nutrient values are \% dry weight (data taken from Kaehler \& Kennish 1996)

\begin{tabular}{|c|c|c|c|c|c|c|c|c|c|}
\hline Alga & $\mathrm{Abb}$ & Test & $\begin{array}{l}\text { Energy } \\
\left(\mathrm{kJ} \mathrm{g}^{-1}\right)\end{array}$ & $\begin{array}{l}\text { Ash } \\
(\%)\end{array}$ & $\begin{array}{l}\text { Soluble carbohydrates } \\
\qquad(\%)\end{array}$ & $\begin{array}{l}\text { Protein } \\
(\%)\end{array}$ & $\underset{(\%)}{\text { Lipid }}$ & $\begin{array}{c}C \\
(\%)\end{array}$ & $\begin{array}{l}N \\
(\%)\end{array}$ \\
\hline Enteromorpha & Ent & Both & 9.8 & 38.3 & 22.9 & 1.6 & 0.7 & 24.6 & 1.4 \\
\hline Chaetomorpha & Cha & $\mathrm{NC}$ & 10.8 & 42.5 & 20.6 & 4.0 & 1.4 & 30.7 & 3.8 \\
\hline Hincksia & Hin & Both & 15.4 & 22.7 & 8.10 & 9.9 & 1.4 & 36.6 & 3.9 \\
\hline Ulva & Ulv & Both & 10.4 & 32.9 & 20.5 & 1.3 & 0.7 & 26.8 & 2.1 \\
\hline Porphyra & Por & Both & 16.6 & 10.8 & 31.6 & 11.2 & 0.3 & 39.1 & 3.9 \\
\hline Dermonema & Dne & $\mathrm{NC}$ & 14.1 & 27.7 & 33.7 & 4.3 & 1.3 & 33.5 & 3.8 \\
\hline Pterocladia & Pte & $M C$ & 17.3 & 14.1 & 33.3 & 3.7 & 1.4 & 38.5 & 4.6 \\
\hline Endarachne & End & Both & 12.6 & 26.7 & 9.40 & 2.80 & 2.5 & 32.9 & 2.1 \\
\hline
\end{tabular}

since differences in algal availability are more marked. Pterocladia is the only alga in the present study that is available throughout the year and energy and carbon contents are the only nutrients it contains that differ significantly between seasons (Kaehler \& Kennish 1996). No relationship was found between the average nutrient rank for each algal species and its ranking in the feeding preference trials (Pearson Product Moment correlation, $\mathrm{p}<0.05$ ).

\section{DISCUSSION}

Grapsus albolineatus exhibited clear preferences for filamentous algae over foliose algae in all the feeding preference tests. Enteromorpha, Chaetomorpha and Hincksia were consistently eaten in greater amounts than both Ulva and Porphyra. The foliose algae Dermonema, Pterocladia and Endarachne were consumed in insignificant amounts during the experiments. These findings agree with observed feeding preferences on the shore determined with the use of electivity indices (Kennish et al. 1996).

No relationship was found between the nutritional composition or calorific value of the test algae and food choice, a situation which has also been recorded for other organisms (e.g. urchins, Paine \& Vadas 1969, Carefoot 1973; Idotea, Nicotri 1980; herbivorous crabs, Coen 1988). When examining the average nutrient ranks for each species (taking the mean of the ranks for each nutrient, e.g. Hincksia $=3,3,8,2,2,3,2=3.29$ in the order of nutrients used in Table $4 ;$ ash is ranked in reverse), the preferred species were low ranked (Enteromorpha $=8$, Chaetomorpha $=6$, Hincksia $=3$ ). Pterocladia, a species never consumed, was the top ranked species, and Porphyra was second. A problem with ranking the species in this way is that the method assumes that all of the nutrients are equally important to the crab. This may not be the case as energy and protein (or nitrogen) are thought to be relatively more important (White 1993). G. albolineatus is, however, not selecting algae on the basis of overall nutritional composition so other factors must be involved.

The presence of secondary chemicals in the tissues of many marine algae, especially at tropical latitudes (Targett et al. 1992), has been shown to deter feeding in a wide range of herbivores as have synergistic mechanisms between structural and chemical defences (Duffy \& Hay 1990, Duffy \& Paul 1992, Hay et al. 1994). Of the test algae, only Endarachne has been recorded as containing secondary metabolites (Wakefield \& Murray 1995); Chaetomorpha, Enteromorpha and Hincksia (based on values for the closely related Ectocarpus) do not appear to (Wylie \& Paul 1988). The effect of secondary metabolites on the feeding ecology of $G$. albolineatus is, however, as yet undetermined.

Availability has been suggested by many authors as the principal determinant for feeding preference (Nicotri 1980, Kilar \& Lou 1984). The 3 foliose algae were not consumed in these experiments, nor on the shore by Grapsus albolineatus at any time during the year, despite being more abundant than the filamentous algae (Kennish et al. 1996). Porphyra is consumed by the crab only during May, when the abundance of highly preferred green and brown turf species has dropped to $<0.2 \%$ shore cover. When the turf species become more abundant, the crab avoids consuming Porphyra. The laboratory preference data supports this field data since, when $G$. albolineatus was only offered Porphyra, it was consumed in significantly greater amounts than when offered together with Enteromorpha and Hincksia.

All the preferred species are filamentous, indicating that morphology of the algae may be the basis for the crabs' preference. When offered the same test alga (rehydrated kelp), in 2 different forms, the crab consumed more of the filamentous than the foliose form. This test experimentally separated algal morphology from the confounding effect of nutrient content, providing strong evidence that Grapsus albolineatus prefers fila- 
Table 5. Grapsus albolineatus. Net returns per $24 \mathrm{~h}$ of the nutrients measured in 4 of the test macroalgae. Values are mg $24 \mathrm{~h}^{-1}$; consumption rates were determined during the no choice preference test. Values in bold are the maximums

\begin{tabular}{|c|c|c|c|c|c|c|c|}
\hline Alga & $\begin{array}{l}\text { Consumption rate } \\
\qquad\left(m g 24 \mathrm{~h}^{-1}\right)\end{array}$ & Protein & Nitrogen & Lipid & Energy & $\begin{array}{c}\text { Soluble } \\
\text { carbohydrates }\end{array}$ & Carbon \\
\hline Hincksia & 967 & 96 & 38 & 14 & 14.9 & 78 & 354 \\
\hline Enteromorpha & 1072 & 17 & 15 & 8 & 10.5 & 245 & 264 \\
\hline Chaetomorpha & 934 & 37 & 35 & 13 & 10.1 & 192 & 287 \\
\hline Porphyra & 717 & 80 & 28 & 2 & 11.9 & 227 & 280 \\
\hline
\end{tabular}

mentous algae because of their morphology. Supporting information for this has been obtained in the field. During summer in Hong Kong $G$. albolineatus consumes calcified coralline algae (Kennish et al. 1996), although it eats more of an erect species (Corallina sessilis) than the more abundant encrusting species (Neogoniolithon misakiense) even though the nutrient contents of these 2 are very similar (Kaehler \& Kennish 1996).

The feeding behaviour of the crab may explain why filamentous algae are preferred over foliose forms. Grapsus albolineatus feeds with sharp, fine-tipped chelae which it uses to pick algal filaments off the rock surface (Kennish 1995). This feeding mode is in contrast to some other herbivorous crabs; e.g. the majid crab Mithrax prefers to eat large foliose algae (Padina and Laurencia) by tearing off portions of the algae or by manipulating the thallus directly to the oral region using the maxillipeds (Coen 1988). The masking crab Notomithrax ursus feeds in a similar way to Mithrax by using the sharp cutting edges of its chelipeds to cut up foliose algal thalli (Woods \& McLay 1994).

Foliose algae may be too large for Grapsus albolineatus to manipulate with its delicate chelae, resulting in a slower ingestion rate. The crab consumed filamentous algae at a faster rate than for any of the other test algae. This factor is important as the foraging period of G. albolineatus is limited to periods of low tide; therefore the amount of food the crab can eat during this period will be limited by ingestion rate (Kennish 1997 b). Faster ingestion rates for the filamentous as compared to foliose algae would allow $G$. albolineatus to overcome any differences in nutrient composition. The higher consumption rate for Hincksia (filamentous) allows the crab to receive more protein, nitrogen, lipid, energy and carbon than from Porphyra (foliose), despite the fact that Porphyra is richer in all components, except lipid content, than Hincksia (Table 5). The net gain per day of soluble carbohydrate is highest for Enteromorpha, again despite Porphyra having a higher (\%) content (Table 5). This result is a function of the edibility of the alga. Nicotri (1980) stated that food preference can be measured in terms of attractiveness and edibility, and these 2 variables are not necessarily correlated. Attractiveness is the selection between a range of dietary items, whereas edibility is the speed at which the food satisfies the physiological needs of a herbivore but also the ease with which the item is handled and ingested.

In the no choice experiment the edibility of each alga is clearly expressed (Table 5). A theoretically adequate rate of consumption does not mean that the alga will in fact satisfy the crabs' physiological needs, even if the net nutrient intake is higher than the needs, since the alga's contribution to the nutrition of the organism will be further modified by the assimilation efficiency of particular nutrients (Lowe \& Lawrence 1976, Vadas 1977). In the case of protein assimilation efficiency, Grapsus albolineatus assimilates $88 \%$ of the protein in Porphyra and $82 \%$ in Hincksia (Kennish 1996), suggesting that slightly more protein would be assimilated if the crab fed on Porphyra. Combining protein assimilation efficiency with feeding rate to calculate gain of protein per unit of time, however, the crab will assimilate $70.8 \mathrm{mg}$ $24 \mathrm{~h}^{-1}$ from Porphyra and $78.9 \mathrm{mg} 24 \mathrm{~h}^{-1}$ from Hincksia. When $G$. albolineatus was given different diets, one containing $25 \%$ Porphyra, another containing $25 \%$ Hincksia, the physiological condition of crabs fed on the latter diet was superior (Kennish 1996), reinforcing the view that Hincksia and turf algae are better able to meet the nutritional demands of $G$. albolineatus as compared to foliose algae.

The observed preferences of Grapsus albolineatus in the laboratory and in the field appear to be based on various interlinked factors which include: the morphology of the algal species; the feeding apparatus of the $\mathrm{crab}_{\text {; }}$ and the net nutrient gain over time (a function of the nutritional value of the food source, the ingestion rate, the assimilation efficiency and the uptake of specific nutrients). Of the range of algae available to the crab, the filamentous algae appear to be the most appropriate to optimise the physiological needs of the crab. G. albolineatus, therefore, is behaving according to the predictions of Nicotri (1980) and Watanabe (1984) in that, when it is offered a choice, the preferred algae are those which contribute most to the physiological condition and fitness of the organism. 
Acknowledgements. The authors thank Mak Yiu Ming and Maria Christina Rohrs for helping us catch the crabs used in the experiments. The manuscript was improved thanks to the highly constructive comments of Prof. Steven Murray (California State Unıversity), Dr Joe S. Y Lee, Mak Yiu Ming and Sven Kaehler (The University of Hong Kong, HKU). R.K. acknowledges firstly the support of a HKU studentship and later a RCG grant to G.A.W. This study represents part of the PhD dissertation of R.K. at HKU. Final thanks go to Kelly Lau for technical support at the last minute due to R.K. being in plaster.

\section{LITERATURE CITED}

Arrontes J (1990) Diet, food preference and digestive efficiency in intertidal isopods inhabiting macroalgae. J Exp Mar Biol Ecol 139:231-249

Beever III JW, Simberloff D, King L (1979) Herbivory and predation by the mangrove tree crab Aratus pisonit. Oecologia 43:317-328

Birch DW (1979) Food preferences of Hemigrapsus nudus (Dana, 1851) (Decapoda, Grapsidae) on San Juan Island, Washington, U.S.A. Crustaceana 36:186-188

Carefoot TH (1973) Feeding, food preference and uptake of food energy by the supralittoral isopod Ligia pallisii. Mar Biol 18:228-236

Carefoot TH (1980) Studies on the nutrition and feeding preferences of Aplysia: development of an artificial diet. J Exp Mar Biol Ecol 42:241-252

Choat JH (1991) The biology of herbivorous fishes on coral reefs. In: Sale PF (ed) The ecology of fishes on coral reefs. Academic Press, San Diego, p 120-155

Coen LD (1988) Herbivory by Caribbean majid crabs: feeding ecology and plant susceptibility. J Exp Mar Biol Ecol 122 $257-276$

Duffy JE (1991) Food and shelter as determinants of food choice by an herbivorous marine amphipod. Ecology 72 1286-1298

Duffy JE, Hay ME (1990) Seaweed adaptations to herbivory Bioscience 40:368-375

Duffy JE, Paul VJ (1992) Prey nutritional quality and the effectiveness of chemical defenses against tropical reef fishes. Oecologia 90:333-339

Hay ME, Kappel QE, Fenical W (1994) Synergisms in plant defenses against herbivores: interactions of chemistry. calcification, and plant quality. Ecology 75:1714-1726

Hay ME, Steinberg PD (1992) The chemical ecology of plantherbivore interactions in marine versus terrestrial communities. In: Rosenthal GA, Berenbaum MR (eds) Herbivores: their interactions with secondary plant metabolites. Evolutionary and ecological processes. Academic Press, San Diego, p 371-413

Hiatt RW (1948) The biology of the lined shore crab, Pachygrapsus crassipes Randall. Pac Sci 2:135-213

Horn MH (1989) Biology of marine herbivorous fishes. Oceanogr Mar Biol Annu Rev 27:167-272

Jensen KR (1983) Factors affecting feeding selectivity in herbivorous Ascoglossa (Mollusca: Opisthobranchia). J Exp Mar Biol Ecol 66:135-148

Kaehler S, Kennish R (1996) Summer and winter comparisons in the nutritional value of marine macroalgae from Hong Kong. Bot Mar 39:11-17

Kennish R (1995) Seasonal patterns of algal availability, influences on diet selection and fitness of the tropical crab Grapsus albolineatus. PhD thesis, University of Hong Kong
Kennish R (1996) Diel composition influences the fitness of the herbivorous crab Grapsus albolineatus. Oecologia 105 : $22-29$

Kennish R (1997a) Seasonal patterns of food availabulity: influences on the reproductive output of the herbivorous crab Grapsus albolineatus. Oecologia (in press)

Kennish R (1997b) Foraging behaviour of the tropical herbivorous crab, Grapsus albolineatus: time minimiser or nutrient maximiser? In: Morton LB (ed) Proceedings of the Third International Conference on the Marine Biology of the South China Sea (in press)

Kennish R, Williams GA, Lee SY (1996) Algal seasonality on an exposed rocky shore in Hong Kong and the dietary implications for the herbivorous crab Grapsus albolineatus. Mar Biol 125:55-64

Kilar JA, Lou RM (1984) Ecological and behavioural studies of the decorator crab, Microphrys bicornutus Latreille (Decapoda: Brachyura); a test of the optimum foraging theory. $J$ Exp Mar Biol Ecol 74:157-167

Lee MAB (1988) Food preferences and feeding behaviour of the land crab Cardisoma carnifex. Micronesica 21:274-279

Littler MM, Littler DS. Taylor PR (1983) Evolutionary strategies in a tropical barrier reef system: functional-form groups of marine macroalgae. J Phycol 19:229-237

Lowe EF, Lawrence JM (1976) Absorption efficiencies of Lytechinus variegatus (Lamarck) (Echinodermata: Echinoidea) for selected marine plants. J Exp Mar Biol Ecol 21: $223-234$

Lubchenco J, Gaines SD (1981) A unified approach to marine plant-herbivore interactions. I. Populations and communilies. Annu Rev Ecol Syst 12:405-437

Manly BFJ (1993) Comments on design and analysis of multiple-choice feeding preference experiments. Oecologia 93:149-152

Nicotri ME (1980) Factors involved in herbivore food preference. J Exp Mar Biol Ecol 42:13-26

Norton TA, Hawkins SJ, Manley NL, Williams GA, Watson DC (1990) Scraping a living: a review of littorinid grazing. Hydrobiol 193:117-138

Paine RT, Vadas RL (1969) Calorific values of benthic marine algae and their postulated relation to invertebrate food preference. Mar Biol 4:79-86

Peterson CH, Renaud PE (1989) Analysis of feeding preference experiments. Oecologia 80:82-86

Prince JS, LeBlanc WG (1992) Comparative feeding preference of Strongylocentrotus droebachiensis (Echinoidea) for the invasive seaweed Codium fragile ssp. tomentosoldes (Chlorophyceae) and four other seaweeds. Mar Biol 113:159-163

Roa R (1992) Design and analysis of multiple-choice feedingpreference experiments. Oecologia 89:509-515

Robertson AI, Lucas JS (1983) Food choice, feeding rates, and the turnover of macrophyte biomass by a surf-zone inhabiting amphipod. J Exp Mar Biol Ecol 72:99-124

Steinberg PD (1985) Feeding preferences of Tegula funebralis and chemical defenses of marine brown algae. Ecol Monogr 55:333-349

Targett NM, Coen LD, Boettcher AA, Tanner CE (1992) Biogeographic comparisons of marine algal polyphenolics: evidence against a latitudinal trend. Oecologia 89 $464-470$

Vadas RL (1977) Preferential feeding: an optimization strategy in sea urchins. Ecol Monogr 47:337-371

Wakefield RL, Murray SN (1995) Food preferences in the herbivorous kelp snail Norrisia norrisi. In: Lindstrom SC, Chapman DJ (eds) XVth International Seaweed Symposium, Valdivia, Chile (abstract) 
Watanabe JM (1984) Food preference, food quality and diets of three herbivorous gastropods (Trochidae: Tegula) in a temperate kelp forest habitat. Oecologia $62: 47-52$

Watson DC, Norton TA (1985) Dietary preferences of the common periwinkle, Littorina littorea (L.). J Exp Mar Biol Ecol 88:193-211

White TCR (1993) The inadequate environment: nitrogen and the abundance of animals. Springer-Verlag, Berlin

Wikelski M. Trillmich F (1994) Foraging strategies of the Galapagos marine iguana (Amblyrhynchus cristatus): adapting behavioural rules to ontogenetic size change.

This article was submitted to the editor
Behaviour 128:255-279

Wolcott DL, O'Connor NJ (1992) Herbivory in crabs: adaptations and ecological considerations. Am Zool 32:370-381

Woods CMC, McLay CL (1994) Masking and ingestion preferences of the spider crab Notomithrax ursus (Brachyura Majidae). NZ J Mar Freshwat Res 28:105-111

Wylie CR, Paul VJ (1988) Feeding preferences of the surgeon fish Zebrasoma flavescens in relation to chemical defenses of tropical algae. Mar Ecol Prog Ser 45:23-32

Zar JH (1996) Biostatistical analysis. Prentice-Hall, Englewood Cliffs, NJ

Manuscript first recelved: August 6, 1996

Revised version accepted: December 4, 1996 